Digital Press Social Sciences and Humanities

Developing Academic Supervision Model To Improve Islamic Education (PAI) Teachers' Performance At Madrasah Aliyah (Islamic Senior High Schools)

Alwis, Sufyarma Marsidin Z., Mawardi Effendi and Jalius Jama

Proceeding of The Non-Formal Education International Conference 2020

Alim Harun Pamungkas, Jamaris, Solfema (eds) 


\title{
Developing Academic Supervision Model To Improve Islamic Education (PAI) Teachers' Performance At Madrasah Aliyah (Islamic Senior High Schools)
}

\author{
Alwis*, Sufyarma Marsidin Z., Mawardi Effendi, Jalius Jama \\ Doctoral Program of Education, Universitas Negeri Padang, Padang, Indonesia \\ *e-mail: alwis.mpd@gmail.com
}

\begin{abstract}
The empirical phenomena revealed several problems related to the competence of academic supervision including supervisors' lack of competence in helping teachers solve the problems related to learning activities. This research is R\&D using ADDIE approach. The findings of this research show that: 1) from needs analysis through questionnaires and interviews with the Ministry of Religious Affairs regarding supervisors' competence in general and through FGD activities with teachers and supervisors, it was found that teachers really needed guidance in their professional development from supervisors through their academic supervision, so a model of academic supervision was designed; 2) the stages of ADDIE in the development of the supervision model were conducted as follows: analysis of the academic supervision model design for Madrasah Aliyah Sungai Penuh, design of the academic supervision model for Madrasah Aliyah Sungai Penuh, development of the academic supervision model for Madrasah Aliyah Sungai Penuh, implementation of the academic supervision model to improve PAI teachers' performance at Madrasah Aliyah Sungai Penuh, and evaluation of the implementation of the academic supervision model to improve PAI teachers' performance at Madrasah Aliyah Sungai Penuh; 3) from the statistical analysis through several tests, it was found that this model was practical, relevant and effective in improving PAI teachers' performance at Madrasah Aliyah Sungai Penuh.
\end{abstract}

\section{Keywords}

academic supervision model, islamic senior high school and performance, teachers

\section{Introduction}

Educational supervisors are strategic elements in achieving educational goals within the national, institutional, curricular, and instructional contexts. The world of education is currently experiencing a dilemma. On the one hand, it needs to improve the quality of learning while on the other hand, it faces the demands of stakeholders, and at the same time significant changes in the growth and development of science and technology also rapidly occur. In this context, society demands that school graduates are not left behind and eliminated by such rapid changes.

In general, educational supervision is directed at fostering teachers and school staff. The supervisors are obliged to provide all assistance through guidance and counseling on various aspects of teaching and learning activities so that educational goals can be achieved optimally (Subari, 1994, p. 1). Educational supervisors play an essential role and function in quality control of education, control of learning process, evaluation of education, and improvement of teachers' performance. Due to these various and complex tasks and responsibilities, it is necessary to have educational supervisors who are smart, skillful, and alert so that the quality standards of education can be properly controlled. The supervisors also act as quality control of the learning process. Since they have the responsibility to conduct the quality control process and to evaluate teachers' performance, the educational supervisors must have good mastery regarding these issues. Therefore, it is necessary for the educational supervisors to have more experience, broad insight, and broad knowledge of all matters regarding the efforts to improve the quality of education in general and teachers' performance under their supervision.

Sagala (2010, p. 61) states that the quality of learning is strongly influenced by the professional quality of teachers' performance, so the efforts to improve teachers' professionalism through the supervisors' assistance need to be carried out continuously and get support and attention from those in 
charge of education. The improvement in teachers' professional skills will be more successful when it is carried out by teachers on their own will and efforts. However, most of the teachers still need assistance from others because they do not know or do not understand the types, procedures, and mechanisms for obtaining various indispensable resources to improve their professional skills. One of the assistance needed by the teacher is in the education supervision.

The most important task of the educational supervisors is to provide various alternative solutions to problems in learning. If the problem disrupts the concentration of the teaching and learning process, the educational supervisors should play their role to make improvements in learning. Therefore, supervisors' empowerment is needed to increase their function as a motivator, facilitator, and catalyst for education (Nawawi, 2008, p. 103).

Nowadays, supervision activities conducted by some supervisors are still oriented towards supervision (control) and educational administration as the main object of the supervision, so the atmosphere of the partnership between teachers and supervisors is not established, and teachers even feel psychologically burdened with the thoughts of assessed by the supervisors. Meanwhile, supervision activities will be effective if such a feeling is replaced by a good atmosphere of providing guidance through supervision and fulfilling teachers' other informal needs.

another aspect causing the less meaningfulness of the supervision activities is the inadequate supervision system and the unhealthy mental attitude of the supervisors. The inadequacy of the supervision system is influenced by several aspects, including 1) the supervision still emphasizes administrative aspects and neglects professional aspects; 2) there is very little face-to-face interaction between supervisors and teachers; 3 ) many supervisors have not taught in school for a long time, so they need new knowledge and technology to keep up with the latest development of education; 4) the supervision generally still use the top to bottom process; and 5) the teachers' potentials under supervision are less exploited (Asmani, 2012, p. 167).

Meanwhile, in terms of the unhealthy mental attitude of the supervisors, it can be seen from several indications namely: 1) the professional relationship is stiff and less familiar due to the authoritarian attitude of the supervisor, so the teachers are reluctant to open up to the supervisors; 2) Many supervisors and teachers feel that they are well experienced, so they no longer need to learn; and 3) Many supervisors and teachers feel quickly satisfied with students' learning outcomes (Makawimbang, 2011, p. 72).

The limited number of supervisors with the scientific background of the learning subject they supervise and no special supervision for a certain learning subject also pose an obstacle to the improvement of learning quality and the education system at large. The main requirement to become an educational supervisor is to have professional competence and ability in the supervised field. Another obstacle is that the efforts to introduce educational innovations are not in line with the improvement of supervisors' ability. This is shown through the implementation of teachers' workshops and training that do not involve the supervisors. Therefore, these learning improvement efforts should be carried out thoroughly and continuously to increase both the teachers' and the supervisors' skills.

So far, the teachers who have attended innovation training have not fully implemented the results of this training in the learning process in the classroom. It implies that they do not yet understand the essence and purpose of this innovation even though the innovators or instructors have explained and demonstrated it with great enthusiasm. It is as a result of the absence of motivation from within the teachers themselves (intrinsic motivation), and they are only a sense of obedience to instructions and fear of their superiors.

In the Indonesian schooling system, educational supervision is still limited to physical and formal administrative aspects such as frequency of laboratory use, teachers' attendance at school, and learning programs while supervision on the teaching and learning implementation of learning is not emphasized. However, it does not necessarily mean that the aspects mentioned above do not need to be supervised, but at least the aspects of the learning implementation need to get balanced attention even more than the others.

The development of a supervision model in the dimensions of academic competence is based on (Arikunto, 2004, p. 19) opinion on the principles of supervision: 1) the supervision is to provide guidance and assistance to teachers and other school staff to solve problems and overcome difficulties rather than to find fault. Thus, in conducting supervision, supervisors and school principals must focus on all steps taken by the school including what kind of efforts have been taken to overcome issues and difficulties?; 2) the supervisors provide direct assistance and guidance, meaning that guidance and assistance are not given directly but must be endeavored so that the party concerned will not feel coerced and will be 
opened as well as self-reliant to cope on the problems; 3) if the supervisor plans to provide feedback, it is best to convey it as soon as possible; 4) supervision activities are carried out regularly, for example, once every 3 months; 5) the atmosphere that occurs during supervision should reflect a good relationship between the supervisors and the supervised; 6) to keep the record of what has been done and supervised, it is best for the supervisors to have a brief note containing the important things needed for their report.

The current trend on the implementation of academic supervision only focuses on one supervision technique, namely the school visit supervision of school visits. It shows that there is no opportunity for supervisors to introduce innovations about learning to teachers. Seeing from the above-mentioned statement, the supervisors do not have the opportunity to get information on learning innovations let alone introduce them to the teachers. Another challenge is that the attempts to introduce innovations to teachers are not in line with the improvement in the supervisors' abilities related to these innovations. This is in accordance with (Slameto, 2016), the supervision program usually contains activities that will be carried out to improve teachers' performance in improving learning situations for which they are responsible. In the supervision program, various efforts and actions need to be carried out for the betterment of learning, so that students' learning acceleration can occur to develop their potential because the teachers have better abilities and skills in teaching.

\section{Methods}

This research is development research. Development research is defined as a research method that is deliberately and systematically aims/is directed to find, formulate, improve, develop, produce, test the effectiveness of products, models, methods/strategies/ways, services, certain procedures, which are superior, new, effective, efficient, productive, and meaningful.

According to Sugiyono (2009, p. 164), research and development (R\&D) is a process or steps to develop a new product or to improve an existing product, which can be accounted for. These products are not always in the form of objects or hardware such as books, modules, learning aids but can also be software such as computer programs for data processing, classroom learning, libraries, or educational models. learning, training, guidance, evaluation, management, etc.

This research was conducted in Sungai Penuh, Jambi. Sungai Penuh has 8 Districts, namely Sungai Penuh, Pondok Tinggi, Sungai Bungkal, Hamparan Rawang, Koto Baru, Pesisir Bukit, Tanah Kampung, and Kumun Debai. The potentials for education in Sungai Penuh are quite large. They are extraordinary national assets and need continuous development to develop the quality of education, both at regional and national levels. The potentials for education in Sungai Penuh are indicated by both in terms of the number of institutions and the number of students and teachers at various levels of education ranging from Elementary Education to Higher Education level. Sungai Penuh City which has only officially been established 10 years ago has one State University (IAIN) Kerinci and six Private Universities, namely STKIP M, STIT, STIE, STIA, AMIK, and AKPER.

The research data were analyzed using the mean score and percentage formula. The quality of the development model must have several criteria, namely relevance (content validity), consistency (construct validity), practicality, and effectiveness (Baecher \& Burns, 2020). The validity is needed to assess the quality of the instruments to be used.

The developed model is said to be practical, relevant, and effective if it can be useful in the field according to what the model is developed for (Baecher \& Burns, 2020). Practicality, relevance, and effectiveness tests were carried out to see the feasibility of the academic supervision model.

\section{Research Findings}

\subsection{Need Analysis of Academic Supervision Model Design for Madrasah Aliyah Sungai Penuh}

The design of this model began by examining the theory of the implementation of the academic supervision model, which aims to improve teachers' quality through professional development, and it should be carried out by supervisors who also have the competence and are professional in the field of academic supervision and the field of the learning subject they supervise. The limited number of 
supervisors with the scientific background of the learning subject they supervise and no special supervision for a certain learning subject also pose obstacles to the improvement of learning quality and the education system at large. The main requirement to become an educational supervisor is to have professional competence and ability in the supervised field. Another obstacle is that the efforts to introduce educational innovations are not in line with the improvement of supervisors' ability. This is shown through the implementation of teachers' workshops and training that do not involve the supervisors. Therefore, these learning improvement efforts should be carried out thoroughly and continuously to increase both the teachers' and the supervisors' skills.

The idea of this change originated from the conditions in the field that the teachers faced many problems in learning with no solution either from the principal or from the supervisors even though the teachers really needed this. Thus, this idea should be developed from the bottom (bottom-up), persuasive communication, collaboration between teachers and information providers on ongoing innovations. It is where the supervisors play a very important role to improve the quality of learning, which aims to help teachers improve the learning process through increasing their competence and professionalism. It places the teachers as a very important source in the implementation of innovation (Satori, 1989, p. 133). Socialization of innovations and supervision of learning has the same mission, namely, to improve the quality of learning. The supervisors must also be competent and professional in the field of innovation and in the field of learning supervision.

\subsection{Stages of ADDIE Development Model on the Development of Academic Supervision Model}

\subsubsection{Design of Academic Supervision Model for Madrasah Aliyah Sungai Penuh}

The design of this academic supervision model was formulated after literature surveys on the appropriate academic supervision model to be applied and easy to understand and implement by the supervisors in supervision activities. From several considerations, the selection of steps to apply the academic supervision model was combined with that of Pidarta's (1992) this model is also in accordance with the research findings (Esia-Donkoh \& Ofosu-Dwamena, 2014, pp. 63-82). The design of the supervision model that the author developed and used in this study can be seen in the figure below.

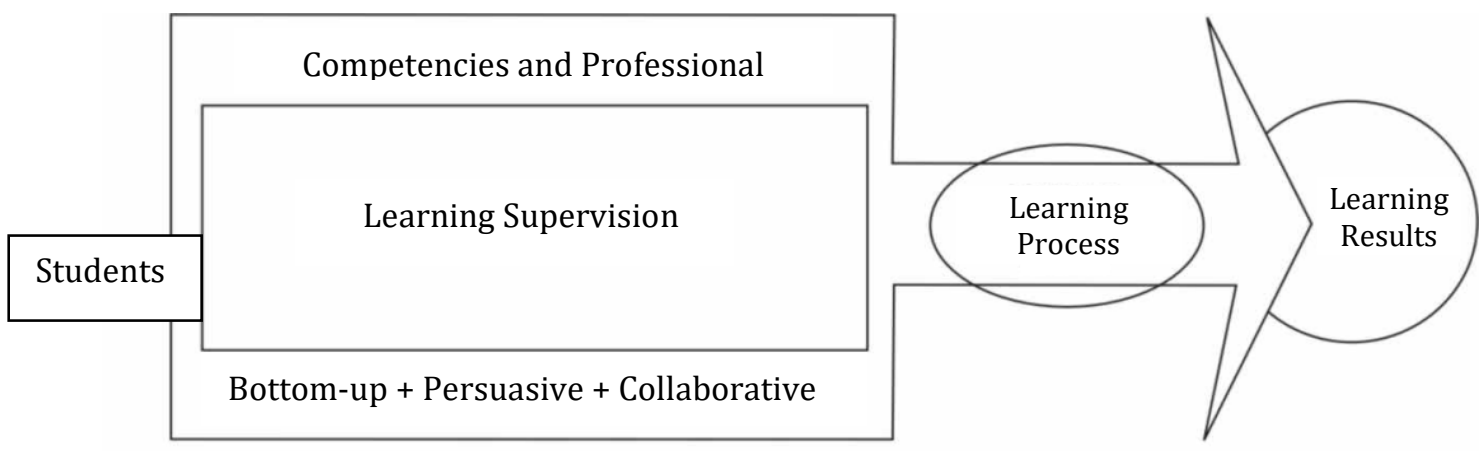

Fig. 1 Design Chart of Academic Supervision Model

\subsubsection{Steps of Academic Supervision Model for Madrasah Aliyah Sungai Penuh}

The above design could not yet be used in the field and was poorly understood by the supervisors, so in this study, the researcher derived the above design into the activity sequences that can be carried out in academic supervision activities. Based on several design tests in the field, the activity sequences that it is easier to understand can be seen in the following figure: 


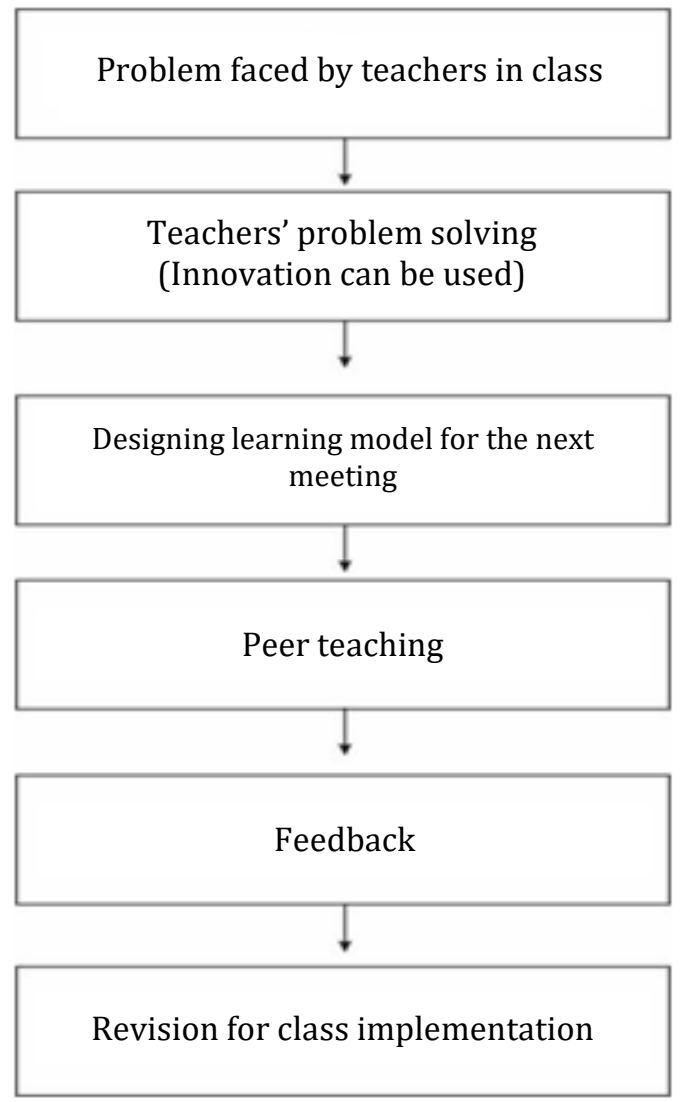

Fig. 2 Chart of Learning Supervision Sequences

This activity is not carried out in the form of a class in which an instructor stands to face a group of participants, but several panelists are in a class together with participants, so the class model is like the following figure:

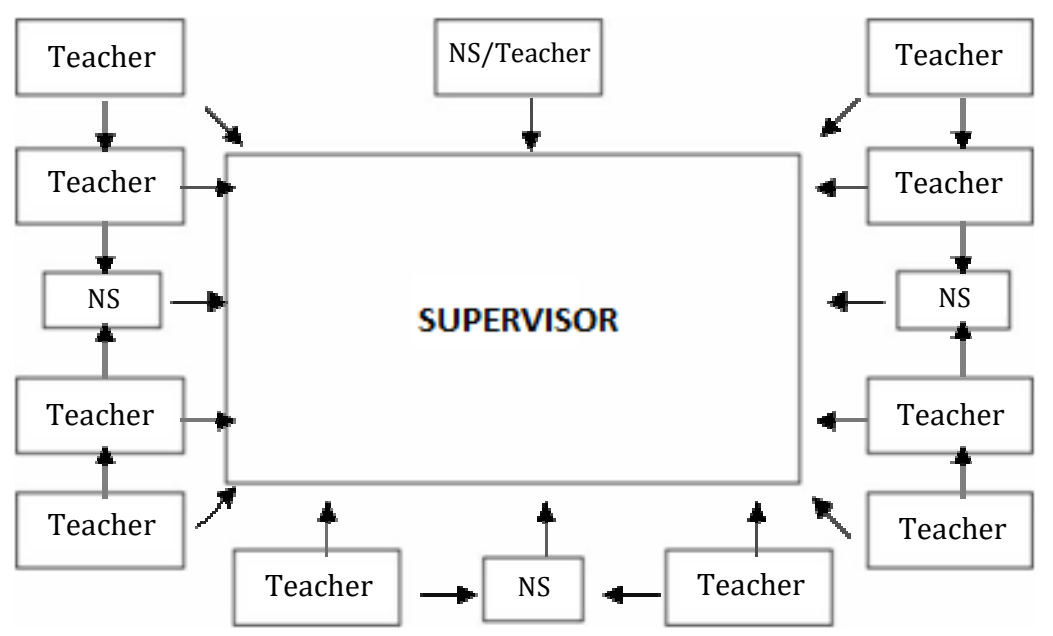

Fig. 3 Chart of Learning Supervision Strategy 


\subsubsection{Hypothetical Model Design}

After the design of the academic supervision model is complete, in order to apply this model, several products/tools are needed to be used simultaneously in helping the activities of this academic supervision model properly and measurably. Thus, Hypothetic Model Design is formed. The initial model is represented as follows:

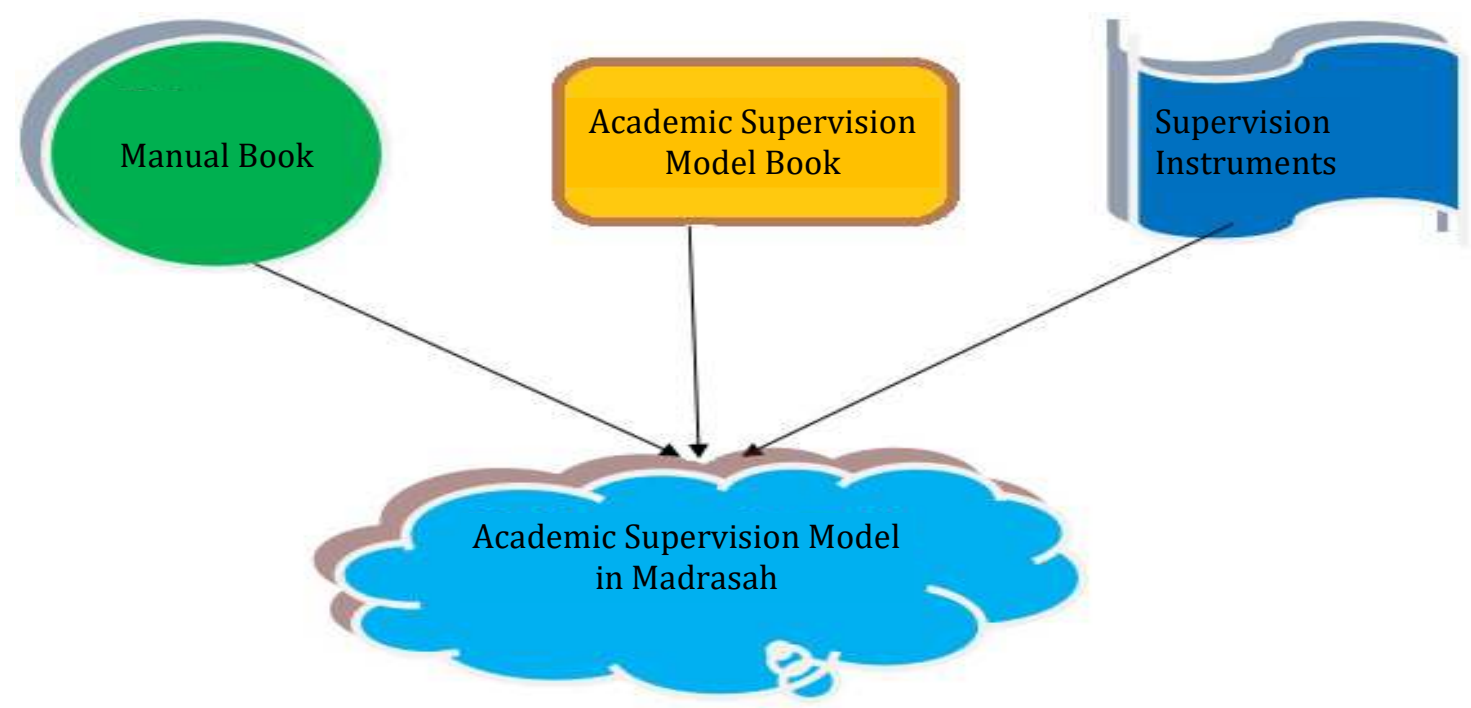

Fig. 4 Initial Hypothetical Model

Table 1 The Effect of the Implementation of Academic Supervision Model Using Academic Supervision Guidebook on the Teachers' Task Fulfillment in Madrasah

\begin{tabular}{|c|c|c|c|}
\hline \multirow{2}{*}{ Task Aspect } & \multicolumn{3}{|c|}{ Result of the Implemented Model } \\
\hline & Ease & Similarity & Difficulty \\
\hline $\begin{array}{l}\text { Preparing Instructional } \\
\text { Plans }\end{array}$ & $\begin{array}{c}80,12 \% \text { on all components } \\
19,88 \% \text { on academic } \\
\text { supervision guidebook }\end{array}$ & $\begin{array}{c}85,23 \% \text { no } \\
12,77 \% \text { on perfomance } \\
\text { instrument arrangement } \\
2,00 \% \text { on academic supervision } \\
\text { guidebook arrangement }\end{array}$ & $\begin{array}{l}20 \% \text { on academic } \\
\text { supervision } \\
\text { guidebook } \\
\text { arrangement }\end{array}$ \\
\hline
\end{tabular}

The data in Table 1 show that by applying the academic supervision model using academic supervision guidebook, $80.12 \%$ of teachers stated that it was easier for them to prepare instructional plans and $82.45 \%$ of them stated that it was easier for them to implement teaching and learning process.

\subsection{Practicality, Relevance, and Effectiveness of Academic Supervision Model}

\subsubsection{Practicality Test}

The practicality test was carried out to determine the level of practicality in using the academic supervision guidebook. The practicality test was carried out by three experts. 
Table 2 Practicality Test

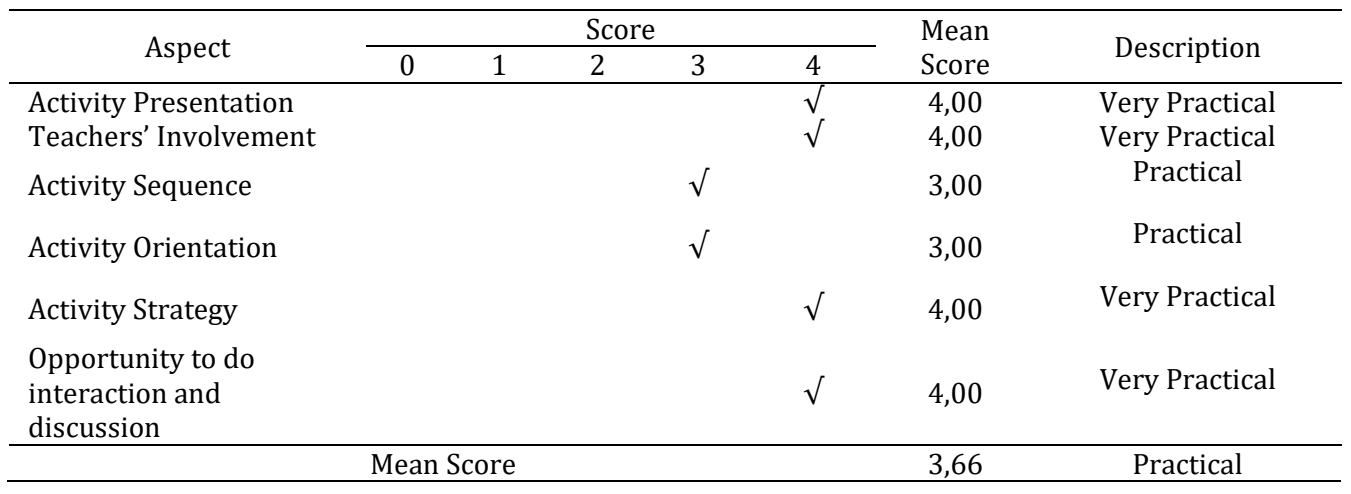

\subsubsection{Practicality Test on Teachers' Performance}

This section descriptively presents the data about teachers' performance in Madrasah Aliyah Sungai Penuh City. These data have derived the result of the teachers' performance measurement filled by the supervisors during the treatment of all research subjects.

Table 3 Frequency Distribution of Teachers' Performance Using Academic Supervision Guidebook

\begin{tabular}{ccccc}
\hline $\begin{array}{c}\text { Interval } \\
\text { Class }\end{array}$ & $\begin{array}{c}\text { Frequency } \\
\text { (fo) }\end{array}$ & $\begin{array}{c}\text { Frequency } \\
\text { (\%) }\end{array}$ & $\begin{array}{c}\text { Cumulative } \\
\text { Frequency (fk) }\end{array}$ & $\begin{array}{c}\text { Cumulative } \\
\text { Frequency (\%) }\end{array}$ \\
\hline $320-326$ & 2 & 8 & 2 & 8 \\
$327-333$ & 3 & 12 & 5 & 20 \\
$334-340$ & 2 & 8 & 7 & 28 \\
$341-347$ & 2 & 8 & 9 & 36 \\
$348-354$ & 0 & 0 & 9 & 36 \\
$355-361$ & 16 & 64 & 25 & 100 \\
\hline Total & 25 & 100 & - & - \\
\hline
\end{tabular}

\subsubsection{Relevance Test on Academic Supervision Model}

The data about the applicability level of the learning model using the academic supervision book are shown in the following table:

Table 4 Frequency Distribution of Relevance of Teachers' Performance before Using Academic Supervision Guidebook

\begin{tabular}{ccccc}
\hline $\begin{array}{c}\text { Interval } \\
\text { Class }\end{array}$ & $\begin{array}{c}\text { Frequency } \\
\text { (fo) }\end{array}$ & $\begin{array}{c}\text { Frequency } \\
\text { (\%) }\end{array}$ & $\begin{array}{c}\text { Cumulative } \\
\text { Frequency (fk) }\end{array}$ & $\begin{array}{c}\text { Cumulative } \\
\text { Frequency (\%) }\end{array}$ \\
\hline $123-128$ & 10 & 40 & 10 & 40 \\
$129-134$ & 7 & 28 & 17 & 68 \\
$135-160$ & 4 & 16 & 21 & 84 \\
$161-166$ & 4 & 16 & 25 & 100 \\
\hline Total & 25 & 100 & 0 & 0 \\
\hline
\end{tabular}

Table 5 Frequency Distribution of Relevance of Teachers' Performance after Using Academic Supervision Guidebook

\begin{tabular}{ccccc}
\hline $\begin{array}{c}\text { Interval } \\
\text { Class }\end{array}$ & $\begin{array}{c}\text { Frequency } \\
\text { (fo) }\end{array}$ & $\begin{array}{c}\text { Frequency } \\
\text { (\%) }\end{array}$ & $\begin{array}{c}\text { Cumulative } \\
\text { Frequency (fk) }\end{array}$ & $\begin{array}{c}\text { Cumulative } \\
\text { Frequency (\%) }\end{array}$ \\
\hline $321-326$ & 2 & 8 & 2 & 8 \\
$327-332$ & 3 & 12 & 5 & 20 \\
$333-338$ & 2 & 8 & 7 & 28 \\
$339-344$ & 4 & 16 & 11 & 44 \\
$345-350$ & 4 & 16 & 15 & 60 \\
$351-356$ & 10 & 40 & 25 & 100 \\
\hline Total & 25 & 100 & - & - \\
\hline
\end{tabular}

From Table 5, the teachers' performance teachers using academic supervision guidebook is in the lowest performance relevance score of 321 and the highest performance score of 356 . The 25 teachers show above-average performance and 5 below average. The most prevalent frequency obtained is in the 
interval class of 351 - 356 and the lowest frequency in 321 - 326. Judging from the average performance score of 20 teachers, it is included that the score is in the relevant category, namely 333-356. It means that the teacher's performance is relevant in the learning process using an academic supervision guidebook, including the practical category with the score of $80 \%$.

\subsubsection{Effectiveness Test}

Effectiveness refers to the conformity between what is expected in using the model with the results of using the model (Baecher \& Burns, 2020). The effectiveness of the academic supervision model is determined by the level of ability of school principals and/or school supervisors in implementing this model.

Table 6 Frequency Distribution of Effectiveness of Teachers' Performance Using Academic Supervision Model Guidebook in the Second Phase of Implementation

\begin{tabular}{ccccc}
\hline $\begin{array}{c}\text { Interval } \\
\text { Class }\end{array}$ & $\begin{array}{c}\text { Frequency } \\
\text { (fo) }\end{array}$ & $\begin{array}{c}\text { Frequency } \\
\text { (\%) }\end{array}$ & $\begin{array}{c}\text { Cumulative } \\
\text { Frequency (fk) }\end{array}$ & $\begin{array}{c}\text { Cumulative } \\
\text { Frequency (\%) }\end{array}$ \\
\hline $321-326$ & 0 & 0 & 0 & 0 \\
$327-332$ & 2 & 8 & 2 & 8 \\
$333-338$ & 3 & 12 & 5 & 20 \\
$339-344$ & 4 & 16 & 9 & 36 \\
$345-350$ & 5 & 20 & 14 & 56 \\
$351-356$ & 11 & 44 & 25 & 100 \\
\hline Total & 25 & 100 & - & - \\
\hline
\end{tabular}

Table 7 Observation Results of the Applicability Level of Academic Supervision Model

\begin{tabular}{|c|c|c|c|c|c|c|}
\hline Aspect & $\begin{array}{l}\text { Applicability } \\
\text { Level }\end{array}$ & MAN 1 & MAN 2 & MAS Arafah & $\begin{array}{l}\text { MAS } \\
\text { Hamparan } \\
\text { Rawang } \\
\end{array}$ & Data Sources \\
\hline \multirow{3}{*}{$\begin{array}{l}\text { Content substance } \\
\text { and design } \\
\text { structure } \\
\text { flexibility }\end{array}$} & High & 88,84 & 83,10 & 86,84 & 84,21 & \multirow{4}{*}{ Teacher } \\
\hline & Average & 8,63 & 13,05 & 13,16 & 10,11 & \\
\hline & Low & 2,53 & 3.85 & - & - & \\
\hline \multirow{3}{*}{$\begin{array}{l}\text { Support for } \\
\text { teachers' task } \\
\text { implementation }\end{array}$} & High & 88,54 & 80,63 & 85,72 & 78,25 & \\
\hline & Average & 7,58 & 16,57 & 6,98 & 6,00 & \multirow[t]{2}{*}{ Teacher } \\
\hline & Low & 3,96 & 2,80 & 7,30 & 7,00 & \\
\hline $\begin{array}{l}\text { Improvement of } \\
\text { teachers; } \\
\text { performance }\end{array}$ & - & Significant & Significant & Significant & Significant & Data Sources \\
\hline \multirow{3}{*}{$\begin{array}{l}\text { Potentials of tools } \\
\text { and materials } \\
\text { availability }\end{array}$} & High & 88,54 & 18,44 & 87,26 & 85 & \multirow{3}{*}{$\begin{array}{c}\text { Teacher and } \\
\text { observation } \\
\text { results }\end{array}$} \\
\hline & Average & 11,46 & 17,56 & 12,74 & 9,45 & \\
\hline & Low & - & 64.00 & - & - & \\
\hline $\begin{array}{l}\text { Potentials of } \\
\text { stakeholders' } \\
\text { support }\end{array}$ & Average & 89,16 & 23,12 & 85,76 & 80 & $\begin{array}{c}\text { Teacher and } \\
\text { observation } \\
\text { results }\end{array}$ \\
\hline
\end{tabular}




\section{Conclusion}

Based on the results of the research findings and discussion, the conclusions can be drawn as follow:

\subsection{The Need for Academic Supervision Model Design for Madrasah Aliyah}

The competence of Academic Supervision is not optimally carried out by supervisors because of the supervision of several components of academic competencies such as lesson plans, basic theories of learning development, syllabus design, and teachers' development only more focused on the administrative check. The supervisors rarely do class visits to see learning activities carried out by the teacher they have not received regular training and activities to support their academic competence in accordance with the current educational innovations, changes, and developments. In contrast, teachers always receive training on changes in curriculum and learning, so supervisors' competence in the academic field is not yet in accordance with the ongoing changes related to learning, and so on.

\subsection{Stages of ADDIE Development Model on the Development of Academic Supervision Model}

\subsubsection{Model Analysis}

The model analysis was conducted through field surveys, field need analysis about academic supervision, and literature review related to academic supervision.

\subsubsection{Design of Academic Supervision Model}

This model is complemented with the use of model books, guidebooks, and academic supervision instruments that can help improve PAI teachers' performance in Madrasah Aliyah (MA) Sungai Penuh. The use of the academic supervision model guidebook indirectly implies a change in teachers' attitudes to change in improving the quality of education in terms of teachers' performance.

\subsubsection{Developing Academic Supervision model for Madrasah Aliyah}

The process of developing the Academic Supervision Model consists of several stages, namely, 1) studying the need to find out the conditions in the field, 2) designing the Academic Supervision guidebook, 3) testing the model guidebook product, 4) carrying out field implementation, and 5) evaluating the developed guidebook (Wiles \& Bondi, 1986).

\subsubsection{Implementation of Academic Supervision Model to Improve PAI Teachers' Performance in Madrasah Aliyah}

As for the applicability of the academic supervision model using the academic supervision guidebook, $80.12 \%$ of supervisors stated that it was easier to prepare a supervision plan and $82.45 \%$ of supervisors stated that it was easier to carry out supervision. The applicability of this model is seen in terms of (a) the content substance $t$ and the flexibility of the design structure, which is flexible enough to be used in several subject matters; and (b) the improvement of teachers' performance, a change in teacher attitudes in making innovative activities in learning.

\subsubsection{Evaluation of the Implementation of the Academic Supervision Model to Improve PAI Teachers' Performance in Madrasah Aliyah}

The implementation of this model can significantly improve teachers' performance, so it also has an impact on the teachers' task to add insight into learning media. The ability to use computers and technology also has an impact on teachers' activities in teaching in a positive direction. 


\subsubsection{Practicality, Relevance, and Effectiveness of Academic Supervision Model}

After conducting several tests, the results of the tests show that the developed supervision model is practical (80\%), relevant (80\%), and effective (76\%).

\subsection{Research Implications}

The academic supervision model can channel government decisions to proclaim and improve the quality of education through improving teachers' performance in the school environment, especially in madrasah because the academic supervision model using the academic supervision guidebook has a better effect on PAI teachers' performance compared to without using academic supervision guidebook. The findings of this study will have strategic implications, especially with regard to PAI learning, namely. It can improve the teachers' performance in madrasah if the supervision is carried out by applying by using academic supervision guidebook as follows: 1) The supervisors prepare academic supervision guidebook which is relevant to the learning material; 2) PAI teachers prepare learning materials; 3) The academic supervision guidebook used provides a guideline for by supervisors in carrying out their duties with the easy steps to apply in accordance with the characteristics of learning; 4) providing solutions to problems that must be changed or improved by PAI teachers in learning; 5) there are feedback and reflection that will be corrected after the supervisors' evaluation by establishing standard instruments to assess the performance of PAI teachers.

\section{References}

Arikunto, S. (2004). Dasar-dasar Supervisi. Jakarta: PT Rineka Cipta.

Asmani, J. M. (2012). Tips Efektif Supervisi Pendidikan sekolah. Jogjakarta: Diva.

Baecher, L. H., \& Burns, R. (2020). Advancing Supervision in Clinically-Based Teacher Education. Journal of Educational Supervision, 3(1), 1.

Esia-Donkoh, K., \& Ofosu-Dwamena, E. (2014). Effects of educational supervision on professional development: Perception of public basic school teachers at Winneba, Ghana. British Journal of Education, 2(6), 63-82.

Makawimbang, J. H. (2011). Supervisi dan peningkatan mutu pendidikan. Bandung: Alfabeta.

Nawawi, H. (2008). Administrasi Pendidikan. Jakarta: CV. Haji Masagung.

Pidarta, M. (1992). Pemikiran Tentang Supervisi Pendidikan. Jakarta: Bumi Aksara.

Sagala, S. (2010). Supervisi Pembelajaran dalam profesi pendidikan. Bandung: Alfabeta.

Satori, D. (1989). Pengembangan Model Supervisi Sekolah Dasar (Penelitian terhadap Efektivitas Sistem Pelayanan/Bantuan profesional bagi Guru-guru Sekolah Dasar di Cianjur Jawa Barat). IKIP Bandung.

Slameto, S. (2016). Supervisi Pendidikan Oleh Pengawas Sekolah. Kelola: Jurnal Manajemen Pendidikan, 3(2), 192-206.

Subari. (1994). Supervisi Pendidikan: Dalam Rangka Perbaikan Situasi Mengajar. Jakarta: Bumi Aksara.

Sugiyono. (2009). Metode Penelitian Pendidikan Pendekatan Kuantitatif, Kualitatif, dan $R \& D$. Bandung: Alfabeta.

Wiles, J., \& Bondi, J. (1986). Supervision: A Guide to Practice. Columbus: Charles E. 